\title{
Energy intakes on sledging expeditions
}

\author{
BY I. T. CAMPBELL* \\ University Department of Anaesthesia, Leeds St James's University Hospital, Leeds 9
}

(Received 25 April 1980 - Accepted 27 June 1980)

\begin{abstract}
1. Previous measurements of energy intake on sledging journeys in Antarctica have given a mean intake of 14.2 MJ (Acheson, 1974; Campbell, 1975), markedly lower than values reported earlier (see Edholm \& Goldsmith, 1966). The technique used (individual weighed-diet survey) was more detailed and could be assumed to be more accurate than most of the earlier work where intakes had been largely inferred from the known energy content of food boxes. In the present study an individual weighed-diet survey was carried out on male subjects during a summer manhauling journey on the east coast of Greenland.

2. Mean daily energy intake of six subjects over $33 \mathrm{~d}$ travelling was $16.5 \mathrm{MJ}$. Mean weight loss was $2.3 \mathrm{~kg}$, probably accounted for entirely by fat loss. Weight loss occurred despite the presence of excess food. Mean daily energy intake rose gradually but persistently over the 5 weeks of the journey despite a constant level of activity and to $20 \cdot 1 \mathrm{MJ}$ during the $4 \mathrm{~d}$ rest at the end of the journey.

3. Intakes were thus higher than those found in the earlier Antarctic studies (Acheson, 1974; Campbell, 1975) but not as high as intakes reported previously (see Edholm \& Goldsmith, 1966). The fact that weight loss occurred despite the presence of excess food was ascribed to the monotonous nature of the diet. The fact that energy intake rose persistently over the 5-week study period may imply that a new state of balance of intake and expenditure was reached.
\end{abstract}

Investigations of food and energy intake on polar expeditions have generally shown daily intakes of 13-17 MJ on base increasing to $21 \mathrm{MJ}$ during sledging. Edholm \& Goldsmith (1966) reviewed previous work on polar nutrition (Masterton et al. 1957; Norman, 1960; Orr, 1965). Mean energy intake of twenty-one subjects sledging was $19.5 \mathrm{MJ}$ but in only four of these subjects was intake measured directly. In the remaining subjects intake was inferred from the known contents of food boxes. Mean body-weight was $78.54 \mathrm{~kg}$ and mean weight loss of seventeen subjects was $1.55 \mathrm{~kg}$.

During 1972 an energy balance survey was carried out at Halley Bay, Antarctica (Acheson, 1974; Campbell, 1975). Food consumption was measured by weighing and recording the intake of each individual as eaten, and energy intake was computed from these results using McCance \& Widdowson's (1969) food composition tables. Seven subjects were studied continuously while travelling for between 1 and 7 weeks. Mean daily energy intake of these individuals on base was 13.0 MJ. In the field daily intake dropped significantly to $12.1 \mathrm{MJ}(P<0.001)$ contrasting with the rise previously found while sledging. Energy intake rose significantly to $14.0 \mathrm{MJ}(P<0.001)$ on return to base. Mean body-weight dropped by $1.98 \mathrm{~kg}$ and was regained on return to base over periods varying between 1 and 6 weeks. Food was plentiful, was at no time rationed and at the end of each journey a considerable quantity was left over.

The methods used in the Halley Bay study were more detailed than those used previously. All individual intakes were measured directly throughout and the results could therefore be assumed to be more accurate. The results differed from previous surveys, however, in that food intake dropped in the field compared to base and were, on average, $6-8 \mathrm{MJ} / \mathrm{d}$ lower than the values obtained by earlier workers. In view of the conflicting findings it was felt that the work should be repeated using the same techniques of measurement. The

\footnotetext{
* Present address: University Dept of Anaesthesia, Royal Liverpool Hospital, Prescot Street, P.O. Box 147, Liverpool L69 3BX.
} 
opportunity to do this was taken during a 5-week manhauling journey on the east coast of Greenland during the summer of 1978.

\section{EXPERIMENTAL \\ Details of expedition}

The Westminster East Greenland Expedition, 1978, spent 5 weeks during July and August travelling through the Crown Prince Frederick Mountains from Tasilaq Fjord (66 $39^{\prime} \mathrm{N}$ $\left.33^{\circ} 33^{\prime} \mathrm{E}\right)$ to a point approximately $130 \mathrm{~km}$ due north $\left(67^{\circ} 51^{\prime} \mathrm{N}\right)$. The area which had never been visited before lies just north of the Arctic Circle approximately $240 \mathrm{~km}$ north east of Angmagssalik, one of the two main centres of population on the east coast of Greenland. The primary scientific objectives were to carry out geological and botanical surveys. Six men took part. They travelled on foot and on ski, and hauled all food and equipment on two sledges, three men to each sledge. Virtually all travelling was over snow-covered glaciers, generally between altitudes of 1000 and $3000 \mathrm{~m}$. A period of $33 \mathrm{~d}$ was actually spent on the journey and a further $4 \mathrm{~d}$ were spent packing up and travelling by local boat to Angmagssalik.

\section{Diet}

The diet was the same throughout. Breakfast consisted of porridge or meusli, midday meal of peanuts, raisins and chocolate and the evening meal of soup and a main dish of meat and vegetables. Biscuits, cheese and margarine were available with all meals.

\section{Subjects}

Details of all subjects are given in Table 1. Mean age was 35 years, mean weight at the start of the expedition $77.8 \mathrm{~kg}$ and mean height $1.83 \mathrm{~m}$.

\section{Methods}

Energy intake. Subjects weighed and recorded every item of food eaten throughout the expedition from the time the local boat dropped them at Tasilaq Fjord until return to the main settlement $37 \mathrm{~d}$ later. Discrete food items such as biscuits and chocolate bars were not weighed individually but the numbers consumed were recorded and a mean weight taken. Tea and coffee were not weighed but added milk and table sugar were.

Skinfold thickness. At the start of the expedition and at weekly intervals throughout the study period skinfold thicknesses were measured for all subjects over the mid-point of the biceps, the mid-point of the triceps, just below the inferior angle of the scapula and just above the iliac crest in the mid-axillary line. All measurements were made on the right side of the body using Harpenden skinfold calipers (Edwards et al. 1955). Percentage body fat was derived from the table of Durnin \& Rahaman (1967).

Body-weight. All subjects were weighed to the nearest $0.1 \mathrm{~kg}$ on a steel-yard bench platform scale at the start of the expedition and again immediately on return to Angmagssalik, $4 \mathrm{~d}$ after the end of the sledge journey.

All statistical comparisons were made using the Student's $t$ test for matched values.

\section{RESULTS}

Mean energy intake. Values for the six subjects are given in Table 1 for the $33 \mathrm{~d}$ spent travelling and for the $4 \mathrm{~d}$ at the end of the sledge journey. Mean daily energy intake while travelling was $16.5 \mathrm{MJ}$ and increased to $20 \cdot 1 \mathrm{MJ}$ in the $4 \mathrm{~d}$ after the journey finished, a rise of $3.6 \mathrm{MJ}(P<0.001)$. The percentage contribution to total energy was 38 from fat, 47 from carbohydrate and 15 from protein. The corresponding values for the $4 \mathrm{~d}$ at the end of the journey were similar: $37 \%$ from fat, $48 \%$ from carbohydrate and $15 \%$ from protein. 
Table 1. Personal details of all subjects, mean daily energy intake while sledging and mean daily energy intake for $4 d$ at the end of the journey

\begin{tabular}{cccccc}
\hline \hline & & & \multicolumn{2}{c}{ Mean energy intake (MJ) } \\
\cline { 5 - 6 } $\begin{array}{c}\text { Subject } \\
\text { no. }\end{array}$ & $\begin{array}{c}\text { Age } \\
\text { (years) }\end{array}$ & $\begin{array}{c}\text { Wt } \\
(\mathbf{k g})\end{array}$ & $\begin{array}{c}\text { Height } \\
(\mathbf{m})\end{array}$ & $\begin{array}{c}\text { While } \\
\text { sledging }\end{array}$ & $\begin{array}{c}\text { At finish of } \\
\text { journey }\end{array}$ \\
\hline 1 & 50 & 69.3 & 1.83 & 13.0 & 16.9 \\
2 & 44 & 74.0 & 1.88 & 19.0 & 18.4 \\
3 & 38 & 92.2 & 1.94 & 16.8 & 20.7 \\
4 & 32 & 68.3 & 1.66 & 16.0 & 21.5 \\
5 & 25 & 75.0 & 1.87 & 16.3 & 20.2 \\
6 & 21 & 88.2 & 1.85 & 18.0 & 22.7 \\
Mean & 35 & 77.83 & 1.838 & 16.5 & 20.1 \\
\hline \hline
\end{tabular}

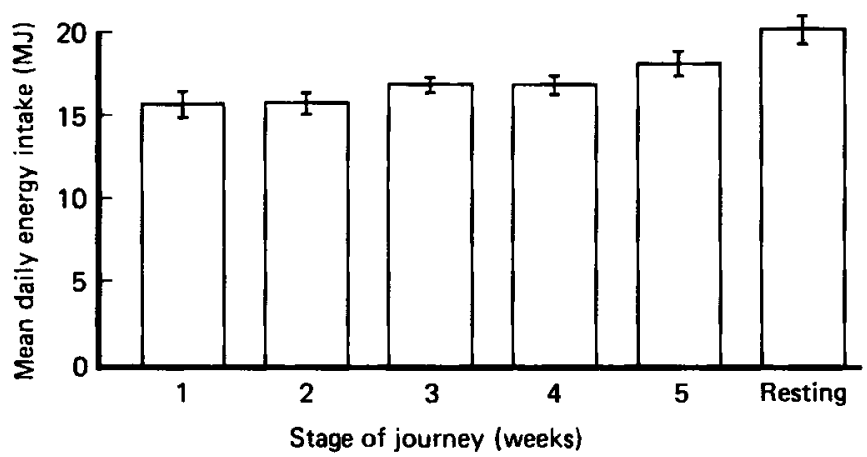

Fig. 1. Mean daily energy intake (MJ) for six subjects during each week of the sledging journey in Greenland and during the rest period at the end of the journey. The vertical bars represent the standard errors.

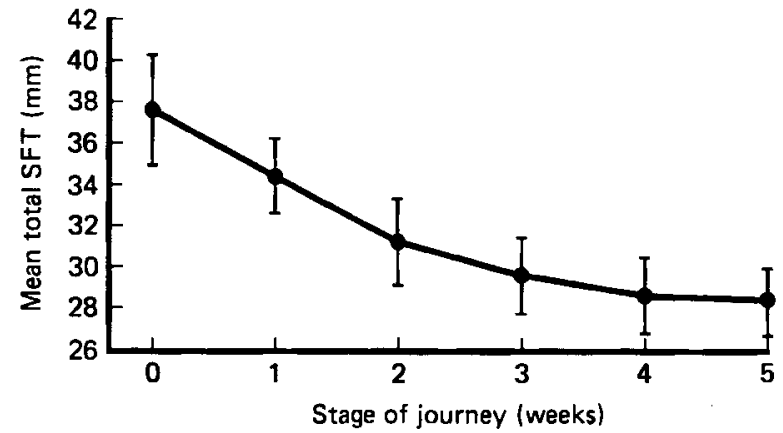

Fig. 2. Mean total skinfold thickness (SFT; mm) of six subjects measured at the start of the sledging journey in Antarctica and weekly thereafter. SFT was measured at the sites described by Durnin \& Ramahan (1967). The vertical bars represent the standard errors.

Mean ( $\pm \mathrm{SE}$ ) daily energy intakes for each week (the fifth week consisting of only $5 \mathrm{~d}$ ) are shown in Fig. 1. Mean intake gradually but steadily rose from $15.6(0.8) \mathrm{MJ}$ in the first week to $15.7(0.5), 16.8(0.3), 16.8(0.5)$ and $18.1(0.8) \mathrm{MJ}$ in the following weeks during the journey and $20.1(0.9) \mathrm{MJ}$ while resting afterwards. All mean daily intakes from the third week onwards were significantly greater than the mean daily intake during the first week $(P<0.001)$. 
Table 2. Initial and final weights $(\mathrm{kg})$ of all subjects, weight loss and calculated fat loss of six subjects between start of expedition and return to main settlement

\begin{tabular}{ccccc}
\hline \hline Subject no. & Initial wt & Final wt & $\begin{array}{c}\text { Wt } \\
\text { change }\end{array}$ & $\begin{array}{c}\text { Fat } \\
\text { change }\end{array}$ \\
\hline 1 & 69.3 & 67.5 & -1.8 & -2.8 \\
2 & 74.0 & 73.8 & -0.2 & $-1 \cdot 1$ \\
3 & 92.2 & 86.2 & -6.0 & -5.6 \\
4 & 68.3 & 67.0 & -1.3 & -2.37 \\
5 & 75.0 & 71.6 & -3.4 & -3.5 \\
6 & 88.2 & 87.3 & -0.9 & -2.3 \\
Mean & 77.8 & 75.6 & -2.3 & -2.9 \\
\hline
\end{tabular}

Table 3. Summary of daily energy intakes of seven subjects on sledge journeys in Antarctica (Acheson, 1974; Campbell, 1975)

\begin{tabular}{|c|c|c|c|c|c|c|c|}
\hline \multirow[b]{2}{*}{$\begin{array}{l}\text { Subject } \\
\text { no. }\end{array}$} & \multirow[b]{2}{*}{$\begin{array}{r}\text { Wt } \\
(\mathbf{k g})\end{array}$} & \multirow[b]{2}{*}{$\begin{array}{l}\text { Mode } \\
\text { of travel }\end{array}$} & \multirow{2}{*}{$\begin{array}{l}\text { Duration } \\
\text { of } \\
\text { journey } \\
\text { (d) }\end{array}$} & \multicolumn{2}{|c|}{$\begin{array}{l}\text { Mean energy } \\
\text { intake (MJ) }\end{array}$} & \multirow{2}{*}{$\begin{array}{c}\text { Habitual } \\
\text { energy } \\
\text { intake (MJ) }\end{array}$} & \multirow{2}{*}{$\begin{array}{c}\text { Wt } \\
\text { change } \\
(\mathbf{k g})\end{array}$} \\
\hline & & & & Travelling & $\begin{array}{c}\text { Return to } \\
\text { base }\end{array}$ & & \\
\hline 1 & $92 \cdot 11$ & Dog sledge & 19 & $10-3$ & $12 \cdot 0$ & $10 \cdot 2$ & -1.93 \\
\hline 2 & 63.07 & Motor sledge & 14 & 9.8 & 13.7 & 13.7 & -1.53 \\
\hline \multirow[t]{3}{*}{3} & 64.89 & Motor sledge & 14 & 9.9 & - & 11.4 & - \\
\hline & & Dog sledge & 19 & $11 \cdot 0$ & - & - & - \\
\hline & & Manhaul & 20 & $12 \cdot 5$ & 10.9 & - & $-4 \cdot 14$ \\
\hline \multirow[t]{2}{*}{4} & 71.96 & Dog sledge & 21 & $13 \cdot 6$ & 16.9 & 14.8 & -1.6 \\
\hline & & Manhaul & 7 & 14.3 & $15 \cdot 2$ & - & -1.3 \\
\hline 9 & 68.26 & Manhaul & 7 & 13.5 & 15.7 & 13.9 & -1.4 \\
\hline 12 & 70.53 & Dog sledge & 21 & $12 \cdot 7$ & $13 \cdot 0$ & $12 \cdot 7$ & $-2 \cdot 1$ \\
\hline 13 & $63 \cdot 50$ & Manhaul & 20 & 13.0 & 16.0 & $14 \cdot 7$ & -1.8 \\
\hline Mean & 70.62 & - & - & $12 \cdot 1$ & $14 \cdot 2$ & 13.0 & -1.98 \\
\hline
\end{tabular}

Skinfold thickness. The mean ( \pm SE) sum of the values for the four sites for the six subjects is shown in Fig. 2. The decrease in total skinfold thickness was quite rapid initially and then became slower. The drop from $37.6(2.7)$ to $34.4(1.8) \mathrm{mm}$ in the first week was statistically significant $(P<0.001)$ as was the drop from $34.4(1.8)$ to $31.2(2.1) \mathrm{mm}$ in the second week. Values for weeks 3,4 and 5 were $29.6(1.9), 28.6(1.8)$ and $28.3(1.6)$ respectively. Skinfold thickness decreased by only $0.2 \mathrm{~mm}$ during the fifth week.

Body-weights. Values at the start of the expedition and on return to Angmagssalik, $4 \mathrm{~d}$ after the sledge journey finished are given in Table 2. Also shown is the weight loss for each subject and fat loss calculated from body-weight and skinfold thickness. All subjects lost weight. The mean weight loss was $2.3 \mathrm{~kg}$ and mean fat loss was slightly greater at $2.9 \mathrm{~kg}$.

\section{DISCUSSION}

As the results of the earlier Antarctic studies (Acheson, 1974; Campbell, 1975) are not readily accessible they have been summarized in Table 3. The unusual features are the low values obtained for energy intake compared with previously-published work (see Edholm \& Goldsmith, 1966) and the fact that weight loss occurred despite plenty of food being available. 
Mean energy intake of the members of the Greenland expedition was $16.5 \mathrm{MJ}$, higher than in the Antarctic expedition but lower than that reported in Edholm \& Goldsmith's (1966) review.

The explanation put forward for the low energy intake found in Antarctica was that a total of approximately $35-40 \%$ of the time was spent lying up because of bad weather (Campbell, 1975). None of the previous authors stated how much time was lost through bad weather or for other reasons, but a period of the duration previously mentioned is not unusual for polar regions where the weather is fickle and activity often limited accordingly. On the other hand during the Greenland journey only $18 \%$ of the total available travelling time was lost. Travelling was hard with $8-10 \mathrm{~h} / \mathrm{d}$ manhauling, mostly on ski. Mean body-weight was comparable with that for subjects in previous sledging studies (Edholm \& Goldsmith, 1966) but higher than that in the Halley Bay work (Acheson, 1974; Campbell, 1975 ) and mean age was higher than that in any of the previous studies.

Orr (1965) restricted the intakes of the subjects on two sledging journeys to $17 \cdot 1$ and $16.3 \mathrm{MJ} / \mathrm{d}$. This produced weight losses of $2 \cdot 25$ and $3.25 \mathrm{~kg}$. On lifting restrictions on intake but still eating the same diet and still sledging, intake rose from approximately $16.7 \mathrm{MJ} / \mathrm{d}$ to over $37.6 \mathrm{MJ} / \mathrm{d}$ and the weight loss was virtually regained over 3 or $4 \mathrm{~d}$. On the two journeys when no weight loss occurred intakes were in excess of $20.9 \mathrm{MJ} / \mathrm{d}$. On these occasions the subjects were eating a ration larger and more varied than the standard sledging ration. For the $4 \mathrm{~d}$ after the end of the Greenland journey intake rose by $3.6 \mathrm{MJ} / \mathrm{d}$. It was thought this increase was probably due to the greater quantities of dried meat and vegetables that were available, although the nutrient composition of the diet eaten at this time was identical with that on the journey. During this time the subjects were doing little strenuous work and the stress of the journey was absent. There was certainly more time available and more space and comfort in which to prepare food and to eat it, and it is possible that these factors could account for the rise in intake that occurred.

Sledging diets are of necessity monotonous. Boredom with food is very real and could be a factor in limiting intake. If monotony were responsible for keeping intake down, then it is perhaps surprising that food consumption should rise so dramatically during the $4 \mathrm{~d}$ at the end of the Greenland journey and that Orr's (1965) subjects actually doubled their intake when dietary restrictions were lifted as in both these instances the diet remained the same.

Individuals on sledging journeys are disrupted quite abruptly from their normal pattern of life into a completely different environment with different demands on them in terms of energy expenditure and patterns of activity. On the Greenland journey energy expenditure went up from that associated with living a normal civilized sedentary existence to that of pulling a loaded sledge for $8-10 \mathrm{~h} / \mathrm{d}$. Fig. 1 shows the pattern of energy intake over the 5 weeks. Day-to-day activity over this period was constant, days lost because of bad weather being spread equally throughout, but intake rose steadily. The pattern of change in skinfold thickness (Fig. 2) showed an initial fall then a plateau. This, combined with the steadily-rising intake, implies that, over this period, it is possible a new state of balance of intake and expenditure was being achieved. The results suggest that it might take over 5 weeks for this change in balance to occur. Parizkova \& Poupa (1963) studied a group of 16-year-old female athletes during a normal training period, followed by a period of intensive training. Energy intake rose rapidly in the first week of the intensive training period and fell slightly during the ensuing weeks, suggesting that, unlike the Greenland study, energy intake rose immediately to meet the increased energy expenditure. It is possible that the monotony of the sledging diet depressed intake until the extent of negative energy balance was such that the need for energy overcame the dietary boredom. Another possibility is the age difference 
of 20 years between the two groups. Older subjects may take longer to adjust intake to expenditure when faced with an increased expenditure and this may be marked when the diet is monotonous.

The author is grateful to Professor O. G. Edholm for his help and advice, to Dr Elizabeth Evans and the Department of Nutrition, Queen Elizabeth College (University of London) for the loan of dietary scales and for the dietary analysis, to the Wellcome Trust who supported this project with a Travel Grant and to Miss Jean Wilson for secretarial assistance.

\section{REFERENCES}

Acheson, K. J. (1974). The assessment of techniques for measuring energy balance in man. PhD Thesis, University of London.

Campbell, I. T. (1975). The determination of energy balance in man. MD Thesis, University of London.

Durnin, J. V. G. A. \& Ramahan, M. M. (1967). Br. J. Nutr. 21, 681.

Edholm, O. G. \& Goldsmity, R. (1966). Proc. Nutr. Soc. 25, 113.

Edwards, D. A. W., Hammond, W. H., Healy, M. J. R., Tanner, J. M. \& Whitehouse, R. H. (1955). Br. J. Nutr. 9, 133.

McCance, R. A. \& Widdowson, E. M. (1969). The Composition of Foods. London: HM Stationary Office.

Masterton, J. P., Lewis, H. E. \& Widdowson, E. M. (1957). Br. J. Nutr. 11, 346.

Norman, J. N. (1960). Man in the Antarctic. MD Thesis, University of Glasgow.

Orr, N. M. W. (1965). Br. J. Nutr. 19, 79.

Parizkova, J. \& Poupa, O. (1963). Br. J. Nutr. 17, 341. 